Research, part of a Special Feature on Nudging Evolution? Critical Exploration of the Potential and Limitations of the Concept of Institutional Fit for the Study and Adaptive Management of Social-Ecological Systems

\title{
Going Transboundary? An Institutional Analysis of Transboundary Protected Area Management Challenges at Mt Elgon, East Africa.
}

\author{
$\underline{\text { Jón Geir Petursson }}^{l}, \underline{\text { Paul Vedeld }}^{l}$ and $\underline{\text { Arild Vatn }}^{l}$
}

ABSTRACT. We analyze institutional challenges for a joint transboundary protected area regime. Employing the case of Mt Elgon in Uganda and Kenya, we use the concepts of fit and interplay to guide our examination in the challenges of the establishment of a transboundary protected area management (TBPAM) regime. Although transboundary regimes are thought to provide better fit for the resources, fitness is a contested phenomenon. The findings are critical to the perceived benefits of the TBPAM strategy in the form of one, fully integrated regional regime. We reveal how such a regime will be seriously constrained by the interplay of complex institutional factors. We moreover find evidence that TBPAM entails a reintroduction of the old top-down conservation paradigms, counteracting the community conservation attempts. Therefore, policy makers are encouraged to approach critically the daunting exercise of a continuum of TBPAM governance toward fully integrated management within a joint TBPAM regime. Instead, the focus should be on identifying the issues that are truly transboundary in nature and construct governance structures that directly address these. In this paper we suggest that policy makers carry out a clear institutional analysis: disaggregate the real transboundary objects, identify common interests, and look for appropriate content and levels of cooperation. It is no panacea to establish an integrated transboundary regime, even if two protected areas happen to be adjoining.

Key Words: Africa; fit; Kenya; protected areas; institutions; interplay; transboundary conservation; Uganda.

\section{INTRODUCTION}

Protected areas (PA) are a key national policy instrument applied to conserve and manage biodiversity, now encompassing more than $12 \%$ of the global terrestrial area and $15.9 \%$ of total land surface in the East/Southern African region (Chape et al. 2005, Newmark 2008). Despite this substantial scale, there is a general consensus in most of Sub-Sahara that biodiversity conservation and sustainable management of PAs have proved difficult to accomplish. The man versus nature perspective, still implicit in most PA strategies, has contributed to severe social impacts and to a situation in which management failures and park-people conflicts are more the rule than the exception (Neumann 1998, Hutton et al. 2005, Brockington et al. 2006, Norgrove and Hulme 2006, Adams and Hutton 2007). Much more seems to be known about what to conserve than about how to conserve it (Bawa et al. 2004). PA governance in the region has therefore come under considerable cross fire and there is now vivid debate about appropriate institutional arrangements for the governance of these areas (Child 2004, Hutton et al. 2005).

Transboundary protected area management (TBPAM) is an influential extension of PA governance in Africa (Muhweezi et al. 2007, Munthali 2007). It is defined as joint governance of adjacent PAs across boundaries between sovereign countries, seeing the "humanly constructed borders" as disruptive for ecological systems (Van Amerom 2002). This also bears clear resemblance to similar instruments developed in other sectors such as water governance (Moss 2004).
TBPAM constitutes a major institutional design and implementation challenge. Instead of focusing on the role of local level institutions in management, it focuses on institutions at regional and international levels to advance PA governance. When proposing such major institutional change, careful attention must be paid to the wider institutional setting in which specific arrangements are embedded. TBPAM emerges in an institutional "landscape" where a multitude of both conservation and development efforts have been and are being undertaken by a variety of actors at different levels. We therefore argue that to formulate appropriate policies, it is paramount to analyze and understand the challenging institutional "landscapes" TBPAM enters into just as thoroughly as the ecological ones (Barrett et al. 2001). The concepts of fit and interplay are essential to our analysis. Fit refers to the match between the institutional arrangements and the biophysical system, whereas interplay addresses the interaction between specific institutional arrangements or regimes (Young 2002). In relation to the above, we note that no governance structures can be evaluated without reference to an aim (Vatn and Vedeld 2012). Hence, defining fit demands specifying which aspects of the resources and their dynamics are considered important.

TBPAM is proposed at a time when the traditional "fortress" approach in PA governance is under heavy critique. Local communities are excluded from participation and from any consumptive access and even from entering the PAs. New policies that devolve power and seek legitimacy at the local 
Fig. 1. Framework for analyzing resource regimes and their impacts. PA = protected areas.

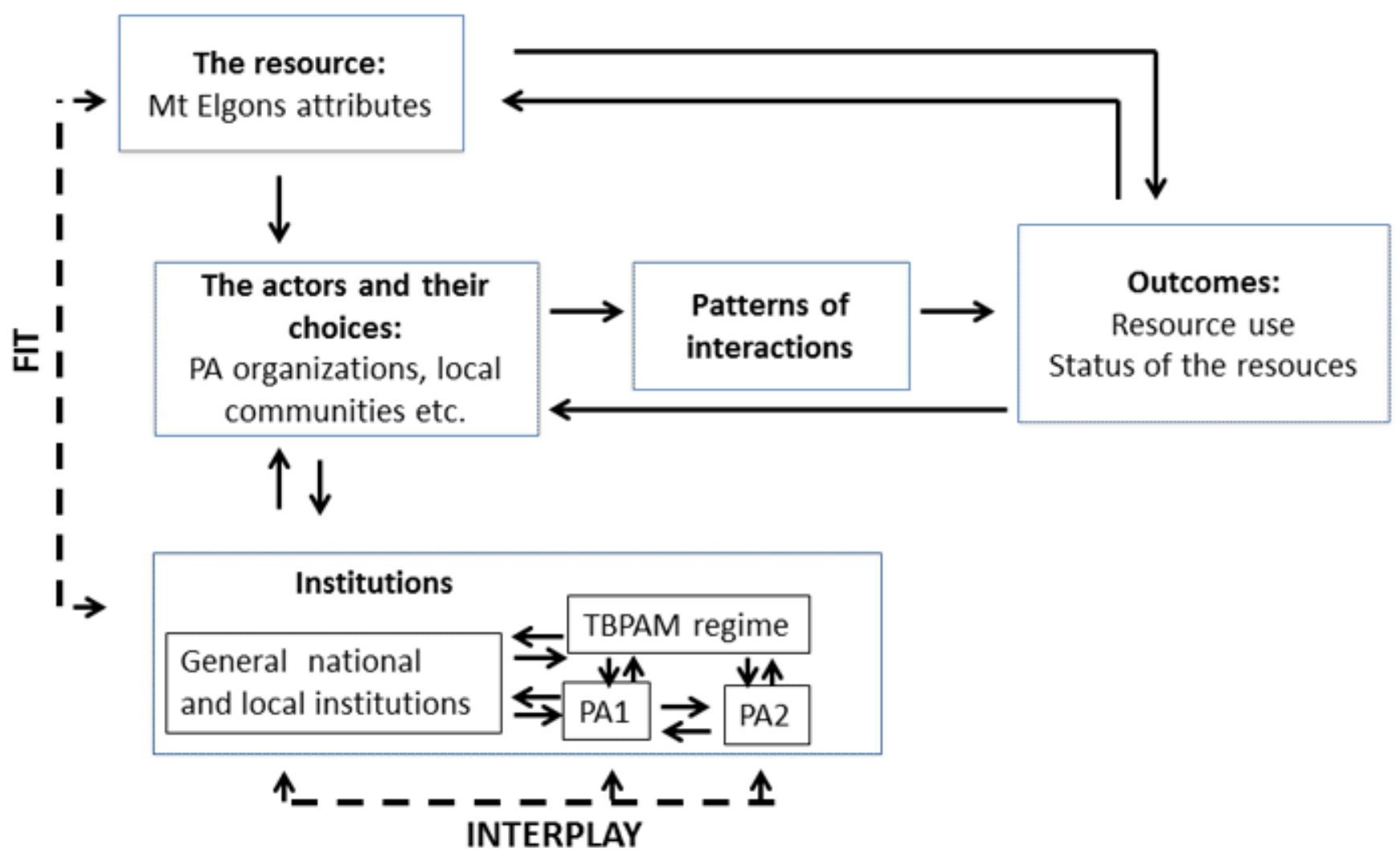

\section{Figure 1. The framework used to analyze PA and TBPAM regimes (based on Vatn 2005).}

community level have become influential alternatives (Barrow et al. 2001). It is now becoming generally accepted that PAs and protection policies are no longer the sole domain of conservationists and foresters, but that it has become part of a much wider economic development and poverty alleviation ambition in many countries (Naughton-Treves et al. 2005). There is, then, a rising critique of the TBPAM interventions being a part of a proconservation renaissance promoted by powerful international conservation actors, described as "back to the barriers," aiming for renewing the traditional socially exclusive "fortress" PA strategies (Hutton et al. 2005, Adams and Hutton 2007).

We question the basic underlying presumption of TBPAM that if only the ecologically most suitable area for conservation is defined, focusing on natural rather than political boundaries, an effective management will more or less automatically evolve (Fall 2005). Our overall research question is therefore: What are key institutional challenges in instituting a fully integrated TBPAM regime including two sovereign countries in the face of already existing national PA structures? We apply institutional analyses to examine the TBPAM approach, employing the case of Mt. Elgon, bisected between Uganda and Kenya, where there is an ongoing process leaning toward instituting a TBPAM regime from the basis of long established PA arrangements. The present study is a part of a broader study by the authors on TBPAM issues on Elgon. Challenges at local level are only partly addressed here but more detailed analyses is found in Petursson et al. (2011).

Our ambition is to advance the understanding of the institutional challenges when considering a TBPAM regime: (1) examine the current PA governance structures on Elgon, (2) assess the institutional challenges of bringing together the current $\mathrm{PA}$ institutional structures into a joint TBPAM regime, (3) assess the fit of a TBPAM regime to Elgon, and (4) scrutinize what level of cooperation the TBPAM regime could entail. 


\section{A FRAMEWORK FOR ANALYZING TBPAM CHALLENGES}

\section{Institutional understanding}

This study uses institutional analyses to examine TBPAM challenges, understanding institutions as formal and informal linkages between human actors and between humans and the environment. Institutions are social practices constructed by humans, consisting of conventions, norms, and formal rules that both guide and are guided by human interaction (Scott 1995, Vatn 2005). Institutions are not static, but evolve and change over time, being historically constituted and reconstituted (North 1990, Vatn 2005). Further, institutions do not operate in isolation, but emerge and evolve into a mosaic of different institutional arrangements at different levels (Cleaver 2002).

PA establishment implies a demarcation between humans and the environment manifested through specific governance structures. Governance in this context means policy making and design of institutions to guide interactions with the resources at stake. Institutional arrangements established to govern protected areas can be conceptualized as resource regimes (Young 2002). This reflects further a distinction between organizations and institutions. We define organizations, like the PA authorities, as actors, whereas institutions are structures that actors shape and are shaped by to create desired outcomes through influencing performance and facilitate coordination and interactions with the environment.

The actors and their choices are important components of our analyses. The assignment of authority, power, rights, and duties in PA conservation is a key aspect in analyzing natural resource governance (Adams and Hutton 2007). Focusing on power relations between actors, often characterized by asymmetries, provides valuable insights in understanding and explaining institutional performance (Robbins 2004). We see PA regimes as political institutions, established and controlled by those who have the power to enforce policies and control outcomes. It is therefore important to examine PA governance in its wider political context. Actors and groups that have power to propose and implement conservation policy changes often have multiple motives, not necessarily considering the public good (Gibson 1999).

Resource regimes are thus central to our analyses. We use an analytical framework to conceptualize key elements of the analysis (Fig. 1). This framework, based on the work of Ostrom (1990), Oakersson (1992), and Ostrom et al. (1994), allows for an analysis of the existing regimes, their fitness to the resource attributes, and the interplay between new and existing institutions. This can further be applied to understand how a TBPAM regime might evolve on the basis of existing PA institutional structures.

\section{Fit and interplay}

We use the concepts of fit and interplay to guide our examination of the challenges and constraints for the establishment of a joint TBPAM regime (Young 2002). As Young's concepts of fit and interplay are relatively loosely defined, we attempt in this section to clarify our understanding and use of the concepts (see also Vatn and Vedeld 2012).

TBPAM can be conceptualized as an attempt to address perceived spatial misfits between resource dynamics and institutions. To analyze fit challenges related to implementation of a TBPAM regime, we examine the congruence of resource attributes that the regime is supposed to govern and the interplay with existing institutional structures in the area. In line with Vatn and Vedeld (2012) we suggest fit to be the more overarching concept covering the relationships between involved institutions/regimes and the biophysical systems (Table 1). Hence, in this study fit refers to how well the institutional arrangements taken together match the defining features of the perceived biophysical problems they address. Interplay becomes then a specific aspect of the then more-encompassing concept of fit, being about the interaction between institutions, new and existing, at both horizontal and vertical levels that next influences the capacities of the institutional arrangement as a whole.

Whereas the analytical content may be rather clear, the operationalization of the nominal concepts of fit and interplay is demanding. The literature does not abound with proposed operational variables or criteria of relevance even if some attempts exist (Brown 2003, Folke et al. 2007, Ekstrom and Young 2009). To guide our analysis on the potential fitness of a TBPAM regime on Elgon, we suggest a set of relevant criteria for our analysis of fit and interplay (Table 1). Figure 1 further outlines how the concept of overall fit, that is, how institutions fit to the ecosystem and interplay, relates to the resource regime analytical framework.

\section{Fit}

As an institutional structure, TBPAM is advocated under the assumption that it offers better fit with the attributes of the natural resources in question compared to current PA arrangements and that it may enhance conservation and sustainability. The concept of fit assumes that the better the fit, the more effective the institution will be in solving management problems (Young 2002, 2008).

According to Folke et al. (2007), the term "fit" addresses how institutions match spatial or temporal scales of ecosystems and account for functional ecosystem processes. Lack of fit or misfit between institutions and ecosystems can be attributed to several factors. Spatial misfits occur according to the authors when the boundary of the institution does not match the boundary of ecosystems. Temporal misfits are related to different time horizons between planning and management on the one side and ecosystems processes on the other. Functional 
Table 1. Assessing the overall fitness of a transboundary protected area management (TBPAM) regime: some key challenges. $\mathrm{PA}=$ protected areas.

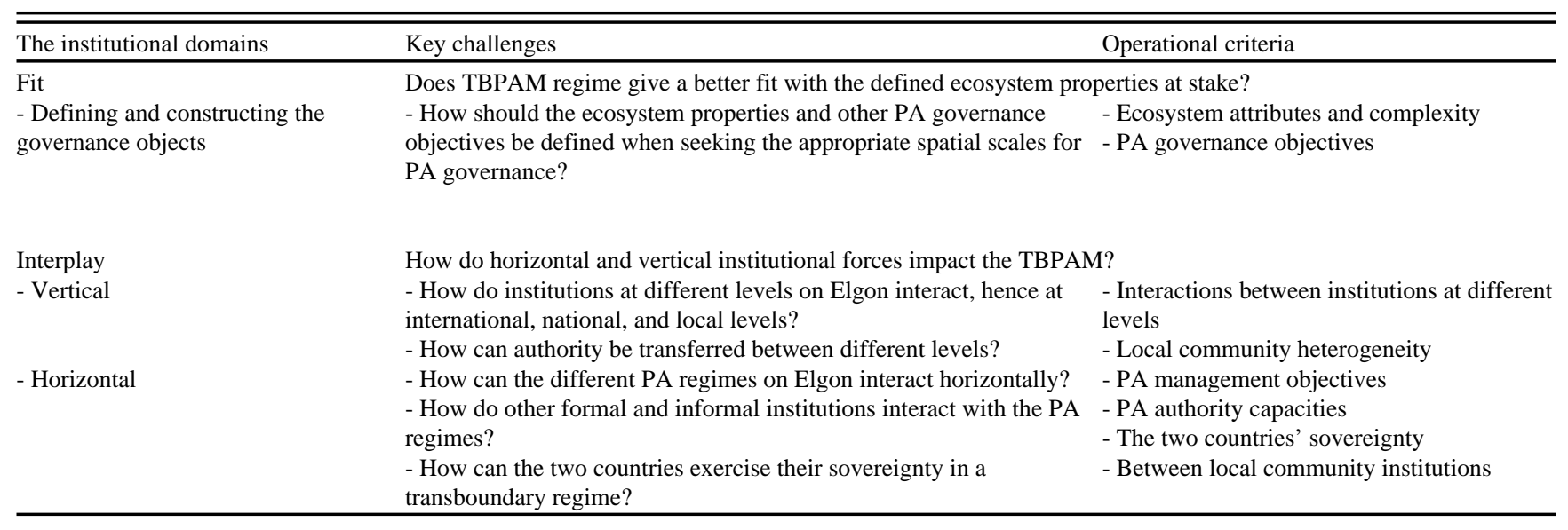

misfits are, finally, misfits in scope in some of the processes that take place in a given institution (Folke et al. 2007).

There is no common or agreed upon definition on what constitutes a good fit. Assessing what is a "better/more advanced fit" will be perceived differently by different actors with varying interests, perceptions, knowledge, and experiences, etc. A PA regime that enforces a strict conservation policy might be effective in delivering conservation outcomes, but might be ineffective in solving local conflicts or securing local political legitimacy.

Identifying ecosystems and their physical boundaries for governance is a necessity, but is still often difficult to implement (Young 2002). This has not only to do with externally given physical characteristics. It relates also to how the physical attributes of the resources is perceived by different actors and what should, therefore, be determining variables when defining the "most suitable" spatial scale of the regime. Most spatial scales are thus not objective or undisputed realities. PA regimes further have governance objectives beyond biodiversity conservation or resource output delivery, such as community collaboration and revenue sharing, security and tourism, which are important when considering the fitness of TBPAM regime.

To assess the potential enhancement of fit by a TBPAM regime, we use two key criteria, outlined in Table 1 . The first relates to governance of different ecosystem attributes and complexities, and the other is PA governance objectives, such as security and tourism. These criteria are then used to provide analysis and discussion of the fitness of the TBPAM regime.

\section{Interplay}

Institutions, such as TBPAM, are not self-contained arrangements, but interact with other institutional arrangements (Young 2002). Interplay between institutional arrangements, both at horizontal and vertical levels, is therefore a major factor when examining the overall fitness of a TBPAM regime. As stated earlier, institutions do not emerge or exist in isolation.

Horizontal interplay emphasizes how regimes at the same level interact in a given system, an important challenge when instituting a TBPAM regime. This draws attention to the principle of sovereignty that entails the inalienable right of the nation state for jurisdiction over its territorial activities and a solid mandate to decide action (Ansell and Weber 1999). It is therefore a challenge if policies that promote TBPAM regime contradict the sovereignty of the involved countries, that otherwise defines the nation states behavior in practice (Van Amerom 2002). Horizontal interplay between the existing national level PA regimes is also important. In most African countries there is a range of PA categories with different jurisdictions (IUCN 1994). The PAs considered in TBPAM can have different jurisdictional status within and between countries, status that is manifested by different management cultures and practices.

Vertical interplay addresses interaction of institutions across different levels of social organization such as local, national, and international. In PA governance, vertical interplay is an important force, especially because of the apparent focus and importance of local level governance and decentralization. The aim of the local level approaches and community strategies is to devolve power and authority from central governments and national authorities to local level actors, especially various types of communities or local governments (Ribot et al. 2006). How such local power can be exercised in a TBPAM, where national and international actors such as national conservation authorities or international conservation NGOs inevitably play a significant role, is a challenging exercise. Moving to international negotiations in transnational 
TBPAM regimes, easily brings back the central national government as the key legitimate management authority and can recentralize the PA governance (Ribot et al. 2006).

Further, there is both horizontal and vertical interplay with other institutions beyond the PA regimes, both formal and informal, that can be a challenge for TBPAM. This relates to institutions governing access to resources and institutions of local government with their administrative boundaries at different levels. ${ }^{[1]}$ We deal mainly with the latter, i.e., the interplay between the formal institutions that have been established and mandated to govern the respective areas (see Petursson et al. 2011 for a discussion of local level institutions).

Interplay is an important issue when studying the fit of alternative institutional arrangements for environmental governance, such as TBPAM. Table 1 offered a set of criteria to guide our analysis on how the interplay between institutional arrangements impacts potential fitness of a TBPAM on Elgon. Concerning horizontal interplay we use four criteria: (1) the management objectives of the different PA regimes; (2) the interest and capacities of the PA regimes; (3) the relations between the two countries involved; and (4) the interplay between local community institutions. For vertical interplay, we use two basic indicators: (1) between institutions at different governance levels from international to local and their power relations; and (2) local community heterogeneity.

\section{The TBPAM approach}

TBPAM is defined as the case when two or more countries decide to establish some level of joint governance of adjoining PAs across national boundaries (Braack et al. 2006). TBPAM can therefore be conceptualized as an international regime, established to realize a better overall fit between institutions and ecosystem attributes. However, there is an immense difference between various visions of TBPAM regimes, between TBPAM as a communication device compared to a full amalgamation of the PA regimes involved (see Table 2). The assumption is that moving along the continuum outlined in Table 2 the level of misfits should gradually decrease and the highest level would indicate the best overall fit between ecosystem and institutions.

Although the first formal TBPAM initiative can be traced back to the U.S.-Canada designation of Waterton-Glacier National Park in 1932, the approach has only recently gained momentum. In 1997, the World Conservation Union (IUCN) formally established a Task Force on Transboundary Protected areas to guide and facilitate their establishment and has actively promoted the concept since (Braack et al. 2006). TBPAM has become widely promoted in southern Africa, partly under the objective of fostering regional peace, hence the term "Peace Parks," with strong influence from the donor community (Van Amerom 2002).
There is an abundance of literature on the possible ecological benefits of TBPAM, arguing that it might enhance fit. Nevertheless, the approach has come under considerable debate. There are actually few empirical studies to date to support the claim that TBPAM improves conservation or development outcomes and is a better fitted regime (Fakir 2000, Hutton et al. 2005, Duffy 2007, Busch 2008). Moreover, there are concerns about vertical interplay, that it can entail a reintroduction of top-down conservation policies, hence, easily alienate local communities.

Actually, the literature is scarce on the interplay challenges implicit in TBPAM and on the level of cooperation necessary (Fall 2009). Some authors note that in the TBPAM discourse, cooperation is perceived as a universal "good thing" in which "more is better" (Fall 2005). We argue on the contrary that identifying the desired level of cooperation between adjoining PA is of crucial importance and that it is unlikely that the same level of cooperation fits all transboundary complexes. Engaging in TBPAM-cooperation often accrues additional transaction costs, is challenged by forces of vertical and horizontal interplay, and puts increased constraints on the often already weak PA authorities.

\section{THE ELGON CASE}

Mt Elgon is a $4321 \mathrm{~m}$ high, solitary dormant volcano just north of the Equator shared by Uganda and Kenya. Both countries came under British colonial rule at the end of the 19th century. The international boundary bisecting the mountain was created by the colonial powers in 1902 and was reified as the current state boundary after independence of Uganda (1962) and Kenya (1963; McEwen 1971). The international boundary divides the two largest ethnic groups native to Elgon, the Sabei/ Sabaot and Bagishu.

Elgon is a significant landscape feature in the region with an extensive base of around $4000 \mathrm{~km}^{2}$, towering the surrounding highlands. The mountain is girded with extensive native forests and softwood plantations and the upper regions contain heaths and moorlands, recorded to harbor exceptional biodiversity of significant global importance (Howard 1991, IUCN 2004). The mountain is further an important water catchment area for the entire subregion.

All lands above the farmlands in both countries belong to some PA regime (Fig. 2). The PAs were initially established during the colonial period in both countries (in the 1930s) and intended to guide hunting and forestry. Since the mid-1960s there has, however, been increased focus on biodiversity conservation, protection of the water catchment functions, and most recently carbon sequestration (Norgrove and Hulme 2006). The current objectives are explicitly to govern wildlife, forests, and water catchment resources and to improve relationships with people of the area (UWA 2000, KFD/KWS 2001). Despite the long standing PA arrangements, environmental degradation has not been avoided. Forest 
Table 2. Typology of levels and types of transboundary protected area management (TBPAM) cooperation between adjoining countries. PA = protected areas.

\begin{tabular}{|c|c|c|c|c|}
\hline Level & $\begin{array}{l}\text { International } \\
\text { relations }\end{array}$ & $\begin{array}{l}\text { Transboundary } \\
\text { PAs }\end{array}$ & Example & Implication for PA governance \\
\hline 0 & & No cooperation & No communication & Although no communications, some knowledge can be assumed \\
\hline 1 & Coordination & Communication & Information sharing & Simple communication on demand \\
\hline 2 & Cooperation & Consultation & Notification of actions & $\begin{array}{l}\text { Requires some knowledge of the actors on the "other side" } \\
\text { Informal institutions } \\
\text { Can be on ad-hoc basis }\end{array}$ \\
\hline 3 & Harmonization & Collaboration & $\begin{array}{l}\text { Active collaboration on several } \\
\text { activities, communication and } \\
\text { meetings }\end{array}$ & $\begin{array}{l}\text { Requires facilitator } \\
\text { Need to establish formal institutions to facilitate the collaboration }\end{array}$ \\
\hline 4 & Association & $\begin{array}{l}\text { Coordination of } \\
\text { planning }\end{array}$ & $\begin{array}{l}\text { Planning for the two protected areas } \\
\text { as a single ecological unit, sometimes } \\
\text { even planning jointly }\end{array}$ & $\begin{array}{l}\text { Close collaboration needed } \\
\text { Need to establish formal institutions } \\
\text { Joint investment and budgeting needed } \\
\text { Decision making negotiated and harmonized }\end{array}$ \\
\hline 5 & $\begin{array}{l}\text { Parallel } \\
\text { national } \\
\text { action }\end{array}$ & Full cooperation & $\begin{array}{l}\text { Fully integrated, ecosystem-based } \\
\text { planning, with common goals and } \\
\text { joint decision making, sometimes } \\
\text { even involving joint management }\end{array}$ & $\begin{array}{l}\text { A fully established TBPAM resource regime } \\
\text { Institutional structures for joint decisions making }\end{array}$ \\
\hline 6 & $\begin{array}{l}\text { Supra- } \\
\text { nationalism }\end{array}$ & Amalgamated & $\begin{array}{l}\text { The TBPAM unit becomes a single } \\
\text { management unit }\end{array}$ & $\begin{array}{l}\text { Power is delegated to intergovernmental authority by involved } \\
\text { governments }\end{array}$ \\
\hline
\end{tabular}

Source: Modified from Fall (2005), based on Taylor (1987) $)^{\dagger}$ and Zbicz (1999)

Fig. 2. The Mt. Elgon area in Uganda and Kenya and the respective protected areas.

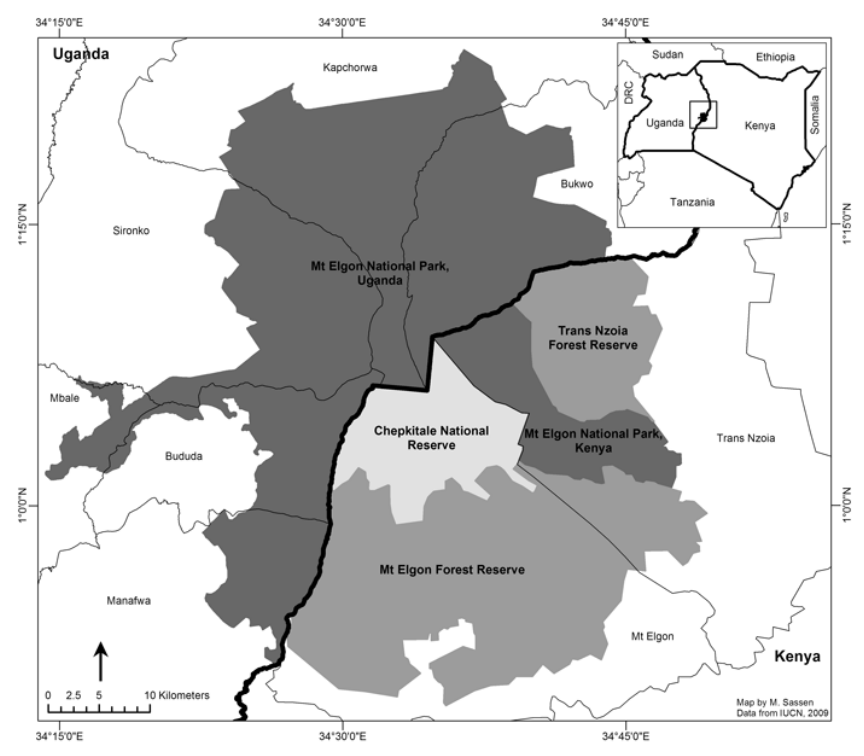

degradation and wildlife depletion are identified as key environmental degradation processes on Elgon (Soini 2007).

The fertile volcanic soils, plentiful rainfall and rich forest resources have provided a base for very high population densities surrounding the PAs, ranging up to 1000 people $/ \mathrm{km}^{2}$ in some local government units (Soini 2007). About 2 million people live in the bordering administrative districts. The surrounding communities in both countries consist predominantly of subsistence small-scale farmers, where the high dependency on mountain natural resources has been extensively studied and verified in both countries (Scott 1998, Myhren 2007). However, the land use Trans-Nzoia district in Kenya partly consists of large commercial and previous colonial settler farms.

Both the PAs establishment and their consecutive governance have sparked significant and violent social conflicts in both countries. The people-PA conflicts essentially relate to rights to land, access to resources, relocations, and resettlements (Norgrove and Hulme 2006, Médard 2010).

The PAs are of key importance for the tourism in both Uganda and Kenya. Because of their significant contribution to the national economies, they are high on the political agenda.

There is an ongoing development project aimed at implementing TBPAM on Elgon (Vedeld et al. 2005). It was initiated and designed by IUCN, funded by Norway via NORAD, and by Sweden, with the aim to improve the conservation and development in the area by joint PA governance $^{[2]}$ (Muhweezi et al. 2007). The formal project ownership is with East African Community (EAC), the facilitating agency has been IUCN, and the national partners are the PA authorities on Elgon: Uganda Wildlife Authority (UWA), Kenya Wildlife Service (KWS), the Kenyan Forest Department (FD), and Mt Elgon County Council (MECC; Vedeld et al. 2005). The aim is to establish a TBPAM governance on Elgon as a pioneer TBPAM regime for East 
Africa (Muhweezi et al. 2007). The TBPAM project was formally launched in 2004 and is still in the process of being realized. Elgon therefore constitutes a relevant and representative case for the study of TBAPM challenges in Africa.

\section{METHODS}

The field data were collected in two phases, in OctoberDecember 2004 and January-April 2008. Firstly, the analyses were based on qualitative data, collected through interviews with national and international level stakeholders on Elgon. The former were Ugandan and Kenyan organizations that have a direct mandate to govern the respective PA on Elgon, that is, UWA, KWS, FD, and MECC. The international stakeholders were those that have direct involvement in the TBPAM initiative on the mountain, that is, IUCN, NORAD, and EAC. The corresponding author conducted semistructured, in-depth interviews with 22 senior officials and 10 junior level officials, asking primarily about PA governance issues and the proposed TBPAM initiative on Elgon. Secondly, the study drew upon a range of PA governance-related studies and assignments by two of the authors Petursson and Vedeld in the area and further, and a series of household questionnaires conducted in local communities addressing local level stakeholders (Baatvik et al. 2002, Vedeld et al. 2005, Petursson et al. 2011). Last, secondary data were collected, especially on PA governance history in Uganda and Kenya, management plans, and practices.

We used the qualitative data from the interviews and the secondary sources to examine how interplay impacts the prospects of bringing multiple PA regimes into a TBPAM system, and further, to examine if a TBPAM can provide a better fit to the ecosystem attributes of Elgon. We have attempted to triangulate the data; from senior level interviews, junior levels interviews, secondary data, and the other studies, to validate data.

\section{ANALYSIS OF PA RESOURCE REGIMES ON ELGON}

We compare and contrast the fitness of the institutional structures that have been established to govern Elgon's natural resources. There are currently five distinct PA resource regimes on Elgon, one in Uganda and four in Kenya (see Table 3 ). We examine the fitness of the individual regimes to Elgon's resources and further, how a TBPAM regime can influence future status of Elgon, using the criteria outlined in Table 1.

\section{Mt Elgon National Park, Uganda}

Mt Elgon National Park Uganda is governed by Uganda Wildlife Authority (UWA), a parastatal, conservation organization, established in 1996. It operates according to the Ugandan Wildlife Act (UWA 2000), which emphasizes biodiversity conservation, while permitting local communities consumptive use of the PA resources and the establishment of revenue sharing programs from gate fees. This enables UWA to enter into negotiations with communities on access to national parks. There has been a long collaboration between UWA and IUCN in the park, funded by NORAD through successive programs since 1988 .

UWA operates under a "paramilitary management culture" and the governance approach has strong focus on law enforcement as the key management instrument that occupies around $4 / 5$ of the approximately 120 rangers. By comparison, the community conservation unit has only 6 rangers. Other studies have indicated excessive use of coercive force when interacting with local communities, an issue that was frequently raised by the local communities during our fieldwork and that is verified in several other studies (see Norgrove and Hulme 2006 for a much more explicit description of the use of coercive power in governing Mt Elgon National Park by UWA). The infrastructure in the park is generally poor, UWA patrols on foot, and there are only basic tourist facilities inside the park. Tourism is limited with approximately 1000 foreign visitors out of the $\sim 800,000$ that annually visit Uganda.

The park encompasses the whole mountain of rugged terrain on the Ugandan side, both forests and the moorlands above the densely cultivated farmlands. The extensive forest areas have been successively degraded, especially during the insurgencies in the Amin and post-Amin reign from 1971-1986. Larger wildlife is extinct on the Ugandan side of Elgon. This extinction was a commonly raised concern by UWA, but mentioned with some relief by the local community members that recalled substantial crop raiding problems from elephants and buffalos in the old days.

The lands surrounding the park are densely populated agricultural areas, with a park boundary some $260 \mathrm{~km}$ long. In most areas, numerous small-scale, subsistence farmers border the park, sustaining their livelihoods from diverse agricultural systems and with a high dependency on park resources. There is a major conflict in many areas revolving around local community access to park resources and boundary disputes (Norgrove and Hulme 2006).

The park was initially announced as a Forest Reserve in 1938, but converted to a National Park in 1993 after the long period of disorder. After the conversion there was an attempt to enforce a "fortress" regime on the whole Ugandan side, excluding local communities' from access. That proved to be an untenable approach, sparking park-community conflicts (White 2002). The proposed solution was to institute formal local access under collaborative agreements between UWA and local communities, in accordance with the Wildlife Act. This has, however been a slow process and to date only been implemented in around half of the parishes ${ }^{[3]}$ that border the park. We found two main reasons: lack of commitment from UWA that blamed the evaporation of donor funding and the 
Table 3. The protected areas (PA) resource regimes operating on Mt Elgon.

\begin{tabular}{|c|c|c|c|c|c|c|c|c|}
\hline \multirow[t]{2}{*}{ PA regime } & \multirow[t]{2}{*}{ Physical setting } & \multirow[t]{2}{*}{ Organization } & \multicolumn{6}{|c|}{ Institutional dimensions } \\
\hline & & & Level & Legal & $\begin{array}{l}\text { Governance } \\
\text { approach }\end{array}$ & Values & Access policy & Capacity \\
\hline $\begin{array}{l}\text { 1. Mt Elgon } \\
\text { National Park } \\
\text { Uganda } \\
\text { (a) parishes } \\
\text { without } \\
\text { collaborative } \\
\text { agreements } \\
\text { (b) parishes } \\
\text { with } \\
\text { collaborative } \\
\text { agreements }\end{array}$ & $\begin{array}{l}\text { Forests and } \\
\text { moorlands } \\
\text { Forest partly } \\
\text { degraded. } \\
\text { Wildlife largely } \\
\text { extinct } \\
100,000 \text { ha }\end{array}$ & $\begin{array}{l}\text { Uganda Wildlife } \\
\text { Authority } \\
\text { (UWA) } \\
\text { Parastatal } \\
\text { conservation } \\
\text { organization. }\end{array}$ & $\begin{array}{l}\text { Central } \\
\text { government }\end{array}$ & $\begin{array}{l}\text { Ugandan } \\
\text { Wildlife Act } \\
2000\end{array}$ & $\begin{array}{l}\text { Conservation } \\
\text { priority. } \\
\text { Understanding of } \\
\text { CA. Legal and } \\
\text { pedagogic } \\
\text { instruments } \\
\text { Coercive power }\end{array}$ & $\begin{array}{l}\text { Ecocentric } \\
\text { values. Nature } \\
\text { conservation } \\
\text { priority }\end{array}$ & $\begin{array}{l}\text { Collaborative } \\
\text { agreements }\end{array}$ & $\begin{array}{l}\text { Modestly } \\
\text { equipped. Poor } \\
\text { infrastructure }\end{array}$ \\
\hline $\begin{array}{l}\text { 2. Mt Elgon } \\
\text { National Park } \\
\text { Kenya }\end{array}$ & $\begin{array}{l}\text { Relatively } \\
\text { pristine. } \\
\text { Forests and } \\
\text { moorlands. } \\
\text { Viable wildlife } \\
\text { populations } \\
17,000 \text { ha }\end{array}$ & $\begin{array}{l}\text { Kenya Wildlife } \\
\text { Service (KWS) } \\
\text { Parastatal } \\
\text { conservation } \\
\text { organization. }\end{array}$ & $\begin{array}{l}\text { Central } \\
\text { government }\end{array}$ & $\begin{array}{l}\text { Wildlife } \\
\text { conservation } \\
\text { and } \\
\text { management } \\
\text { Act, Cap. } 376\end{array}$ & $\begin{array}{l}\text { Strict } \\
\text { protectionism } \\
\text { Legal instruments } \\
\text { Law enforcement } \\
\text { Coercive power }\end{array}$ & $\begin{array}{l}\text { Ecocentric } \\
\text { values. Nature } \\
\text { conservation } \\
\text { priority }\end{array}$ & No access & $\begin{array}{l}\text { Well equipped. } \\
\text { Good facilities } \\
\text { and } \\
\text { infrastructure }\end{array}$ \\
\hline $\begin{array}{l}\text { 3. Mt Elgon } \\
\text { Forest } \\
\text { Reserve } \\
\text { Kenya }\end{array}$ & $\begin{array}{l}\text { Partly degraded, } \\
\text { both native and } \\
\text { plantation forest. } \\
\text { Some wildlife } \\
45,000 \text { ha }\end{array}$ & $\begin{array}{l}\text { Kenya Forest } \\
\text { Department } \\
\text { (KFD) } \\
\text { Government } \\
\text { body. }\end{array}$ & $\begin{array}{l}\text { Central } \\
\text { government }\end{array}$ & $\begin{array}{l}\text { Forestry Act } \\
\text { Cap } 385\end{array}$ & $\begin{array}{l}\text { Sustainable forest } \\
\text { management the } \\
\text { aim. } \\
\text { Economic and } \\
\text { legal instruments }\end{array}$ & $\begin{array}{l}\text { Antroprocentric. } \\
\text { Forest } \\
\text { resources both } \\
\text { used and } \\
\text { conserved }\end{array}$ & $\begin{array}{l}\text { Local } \\
\text { communities } \\
\text { pay for access. }\end{array}$ & $\begin{array}{l}\text { Poorly } \\
\text { equipped }\end{array}$ \\
\hline $\begin{array}{l}\text { 4. Trans- } \\
\text { Nzoia Forest } \\
\text { Reserve } \\
\text { Kenya }\end{array}$ & $\begin{array}{l}\text { Partly degraded, } \\
\text { both native and } \\
\text { plantation forest. } \\
\text { Some wildlife } \\
20,000 \text { ha }\end{array}$ & KFD & $\begin{array}{l}\text { Central } \\
\text { government }\end{array}$ & $\begin{array}{c}\text { (Same as } \\
\text { above) }\end{array}$ & $\begin{array}{l}\text { Sustainable forest } \\
\text { management the } \\
\text { aim. Economic } \\
\text { and legal } \\
\text { instruments. Large } \\
\text { focus on } \\
\text { plantations }\end{array}$ & $\begin{array}{l}\text { (Same as } \\
\text { above) }\end{array}$ & $\begin{array}{l}\text { Local } \\
\text { communities } \\
\text { pay. Timber } \\
\text { concessions to } \\
\text { plantations }\end{array}$ & $\begin{array}{l}\text { Poorly } \\
\text { equipped, but } \\
\text { small area. }\end{array}$ \\
\hline $\begin{array}{l}\text { 5. Chepkitale } \\
\text { National } \\
\text { Reserve } \\
\text { Kenya }\end{array}$ & $\begin{array}{l}\text { No } \\
\text { infrastructure. } \\
\text { Moorlands. } \\
\text { Some wildlife. } \\
17,000 \text { ha }\end{array}$ & $\begin{array}{l}\text { Mt Elgon } \\
\text { County Council. } \\
\text { District local } \\
\text { government }\end{array}$ & $\begin{array}{l}\text { Local } \\
\text { government }\end{array}$ & $\begin{array}{l}\text { Trust land. } \\
\text { Wildlife } \\
\text { conservation } \\
\text { and } \\
\text { management } \\
\text { Act, Cap. } 376\end{array}$ & $\begin{array}{l}\text { Limited } \\
\text { management. } \\
\text { Local grazing. } \\
\text { Collection of } \\
\text { nontimber forest } \\
\text { products }\end{array}$ & $\begin{array}{l}\text { Anthropocentric } \\
\text { moorland and } \\
\text { forest } \\
\text { resources used } \\
\text { by local } \\
\text { communities }\end{array}$ & $\begin{array}{l}\text { Access of local } \\
\text { community } \\
\text { members. No } \\
\text { permanent } \\
\text { settlement } \\
\text { allowed }\end{array}$ & $\begin{array}{l}\text { Very poorly } \\
\text { equipped. }\end{array}$ \\
\hline
\end{tabular}

unsettled boundary disputes in which communities claim tenure rights within the current PA boundary. As long as this dispute is unsettled, it is not likely that communities will enter into contracts to formalize access to resources they claim they already own. It is therefore difficult to propose collaborative agreements because of forces of vertical interplay, as a better fitting institutional arrangement for community access in other PA regimes on Elgon.

The park is, however, closed for resource extraction for all citizens except people from parishes physically bordering the park and thereby having collaborative agreements with UWA. These policies have been challenged by people in parishes not directly bordering the park, but live still close to it and have a historically high dependence on its resources. This horizontal institutional interplay negatively impacts park-people relations.
The Ugandan Wildlife legislation is regarded as progressive on community issues, and Uganda has allowed for a principal change in PA management (Barrow et al. 2001). We find, however, uncertainties regarding who should get access to what in the PA.

When UWA officials were asked about transboundary issues of relevance hence horizontal interplay, they mainly expressed their interest in tourism and security issues. The UWA officials expressed generally positive perceptions toward increased cooperation with their Kenyan counterparts, especially KWS. The two organizations have much in common. Both are relatively recently established parastatal organizations, after a governmental reform guided by the same international consultancy firm. Some staff members were found to have the same educational background, from the Tanzanian College of African Wildlife Management at Mweka, and also had personal connections with colleagues in the other service. 
During our interviews, substantial interest was expressed in learning about the operations of KWS in general, far beyond Elgon as such. This type of horizontal interplay between the two PA regimes could stimulate prospects for a TBPAM to provide both positive interplay, but also possibly better fit on Elgon.

\section{Mt Elgon National Park, Kenya}

The areas considered to be of highest conservation value in MtElgon Forest Reserve in Kenya were converted to Mt Elgon National Park (MENP Kenya) in 1968. It is governed by KWS, a national parastatal conservation body operating according to the Wildlife Conservation and Management Act.

KWS is a large, well equipped conservation organization compared to UWA, with strong self-confidence and a rather strong paramilitary tradition. KWS has vast experience working with international level conservation stakeholders.

The park has relatively good infrastructure, an airstrip, accessible roads, campsites, footpaths, and tourist accommodation facilities. The park office is within the park, but it belongs to a larger subunit within KWS that has its office in Kitale, the neighboring regional center. KWA has ranger outposts in several locations in Elgon, beyond the National Park and operates intelligence units in surrounding communities, meant to identify poaching and other illegal activities. The operative capacity of KWS was found to be far greater than UWA's, both in budgetary terms, human resources, and technical capacity. This difference in capacity can influence the rules of the game in terms of horizontal interplay; between the two PA regimes, UWA would be more interested in cooperation because of perceived learning benefits from the bigger and more experienced KWS.

MENP Kenya constitutes a 17,000 ha transect from the farmlands, across the different forest ecotypes and moorlands to the mountain top. The forests are relatively intact and deforestation has mostly been avoided. It serves as a sanctuary for the remaining wildlife on the mountain, especially elephants, leopards, buffaloes, waterbucks, forest hogs, and some smaller antelope species. KWS has further started to reintroduce wildlife to the park, both giraffe and zebra. Tourism has been comparably low in the park with around 3000 visitors annually, mostly Kenyan residents, out of the $\sim 2$ million annual visitors to all KWS areas. Such PA governance objects are important to understand potential benefits of a TBPAM to enhance fitness on Elgon.

MENP Kenya is governed under a classical "fortress" approach in which the local communities are excluded from any consumptive access or even from entering the park. KWS adopts a strong law enforcement management culture in which well-armed rangers patrol the park against illegal entrance. The park is relatively small compared with other Kenyan national parks with a short community boundary, but the number of rangers is still similar to the approximately 10 times larger Ugandan National Park. KWS is therefore able to enforce relatively effective park protection. KWS is further committed to track the large mammals within the other PA units, because wildlife is state property in Kenya, regardless of its location. The park operates a mobile elephant tracking unit that follows the elephant herds when elephants enter the other PA units on the Kenyan side. This is done in agreement with the other PA authorities that do see KWS as the legitimate actor to oversee the wildlife populations beyond the national park boundaries. There is a memorandum of understanding and a joint management plan between KWS and the Kenyan Forestry Department (FD) to facilitate cooperation in Elgon. This existing institutional arrangement and accompanying resources on the Kenyan side are thus found to be rather effective for wildlife governance.

The farmlands bordering the park became large-scale, white settlers' farms during colonial Kenya. After independence, many of these farms were transferred to state tenure and became operative as state-run enterprises under the Agricultural Development Corporation (ADC), a Kenyan parastatal mandated to run large scale farms on former white settlements so as to promote agricultural development generally in the country. This had a great influence on parkcommunity relations, as few small-scale subsistence farmers bordered the park, making it easier to resolve crop-wildlife disputes. This, however, changed during the land tenure transformations by the Kenyan government from the 1980s. Then some parcels of the state ADC farms were allotted to small scale farmers, mostly close to the national park boundary.

It has now become a major issue for KWS to address parkcommunity relations in light of the more recent settled farms alongside the park. The Kenyan legislation does not allow consumptive resource use in national parks. Since 1991 there is, however, a policy of revenue sharing in which up to $25 \%$ of the gate fees are supposed to be shared with neighboring communities. There is a small revenue sharing program operating, but because of a limited number of visitors, the gate fee incomes are minor. There is a robust electric fence along the park-community boundary, erected as a measure to address park-community interactions. Compared with UWA again, the ambitions for participation in the Kenyan model is much lower. In a TBPAM context, this could generate nonfunctional horizontal interplay by constraining joint policies and efforts on participatory issues in a TBPAM.

KWS' interest in transboundary issues was found to include similar issues as their Ugandan counterparts in UWA, i.e., a general interest to be informed about the activities on the other side of the mountain. The direct management objects were also similar, on tourism and on security. A special issue on tourism was related to accessing the highest peak on the 
Ugandan side because the Kenyan tourists have to enter Ugandan territory to reach this top. Security concerns were found similar to UWA's, but with an additional emphasis on poaching issues. There are claims that poachers cross the boundary from Uganda.

KWS emphasized the need for a strong back-up from their central headquarters if entering into a transboundary venture with Uganda, not least because of the policy of rotating senior wardens between parks. The park has had 28 different senior wardens since its establishment in 1968, meant to constrain any evolution of personal relations between respective park managers, but also resulting in low institutional memory and more myopic leadership within the park administration. Therefore, it was argued that TBPAM issues ought to be nested in the central KWS office in Nairobi.

\section{Mt Elgon and Trans-Nzoia Forest Reserves Kenya}

There are two distinct Forest Reserves on the Kenyan side, Mt Elgon and Trans-Nzoia, both managed by the Forestry Department (FD), a governmental body. There is ongoing organizational reform, converting the FD to the parastatal Kenya Forest Service under a new forest law. During the field work in 2008, the reform was still evolving, but seemingly without any significant impact on the FD practices. It is, however, an aim that the reform will lead to more efficient management and allow for more participatory forest management. Kenya Forest Service is now established and is expanding its operations country wide.

The management objectives of the Forest Reserves are quite different from the National Park. What the two regimes have in common is to prohibit permanent settlement and hunting. Apart from that, the Forest Reserves have been governed for extractive use of the forest resources, both in the native forests and through establishment of softwood plantations. The management culture reflects anthropocentric values, aiming to maximize forest resources and monetary incomes. There are therefore some clear value conflicts between FD and the conservation organizations. There is a memorandum of understanding between FD and KWS as mentioned above.

The FD administration in both districts is badly equipped, with limited resources to supervise and implement forest management operations, and control the forest enterprises that have been granted logging concessions. Therefore, many plantations are exhausted and many accessible areas of the native forest are severely degraded. There have further been substantial claims of mismanagement and rent seeking behavior within the FD. As an anticorruption measure, all staff were fired in 2002 and only partly re-recruited.

The Forest Reserve regimes allow local communities to extract forest products for a fee collected by the FD rangers. Commercial logging is still largely halted for two reasons: the general Presidential Decree banning logging in native forests and because the plantations are in fact largely exhausted (Hitimana et al. 2004).

The senior officials at FD in Mt Elgon and Trans-Nzoia districts did or could not identify many direct forestry related governance objectives that would benefit or be better fitted by a TBPAM regime. Forestry was seen primarily as a national level issue, and it was considered more important to address challenges at the local level in each country than to enter into regional collaboration. They stressed, however, that issues related to security in general were often transboundary in nature and where the administration might benefit indirectly by increased collaboration. Tourism was not raised as a governance priority in the Forest Reserves.

The two Forest Reserves have quite different attributes. The Trans-Nzoia Forest Reserve, being governed from the FD office in Kitale town, is around 23,000 ha, consisting of relatively large areas of softwood plantations. The bordering areas were largely taken over and settled by white farmers during the colonial period, some of which have continued farming after independence. Some farms have been parceled to small-scale farmers whereas others have been converted to large government farms. The forest operations had for a long time a strong focus on the plantations, many of which now are in poor conditions. The surroundings of Mt Elgon Forest Reserve were never settled by colonial farmers and today these areas host numerous small-scale farmers. That has created different dependencies of the PA resources compared with Trans-Nzoia. Furthermore, the area is much larger (around $50,000 \mathrm{ha}$ ) and difficult to oversee. KWS has a large outpost in the Mt Elgon Forest Reserve that they use for their elephant tracking unit and security forces, tracking the elephant herd when it is browsing in the Forest Reserve such as in Chepkitale National Reserve.

Mt. Elgon Forest Reserve has been subject to substantial violent conflict between Sabiny subgroups (Médard 2010). In 2008 , the area was closed because of military interventions. Armed guerillas have been using the forests and large caves in the area as hideouts. This has significantly constrained FD activities and reveals substantial, existing local negative interplay situations that will not be automatically addressed in a TBPAM context.

\section{Chepkitale National Reserve Kenya}

Chepkitale National Reserve (CNR) is the most recently established PA unit on Elgon, crafted out of Mt Elgon Forest Reserve in 2000. It is governed by Mt Elgon County Council, the district local government in Mt Elgon District that has been devolved of its power and full responsibility to govern the area, according to the Kenyan Wildlife Conservation and Management Act. CNR was established under laws of Trust lands, a special state tenure regime whereby the Ministry of Local Government through County Councils holds the land in trust on behalf of the local people. 
There are expectations within the Mt Elgon County council that local governance might provide an opportunity to facilitate tourism and thereby generate revenues for the local economy. However, to date, tourism is almost nonexistent in the reserve because of lack of facilities and security concerns in the district.

CNR is 16,000 ha of heath and moorlands on the high mountain above the main forests in Mt Elgon district. The reserve is interlocked by the other PA units in Kenya and Uganda, hence, does not have any direct borders to communities.

Mt Elgon County Council implements very limited management operations in the area because of insufficient resources and lack of capacity. Despite its situation, the National Reserve regime includes consumptive use, especially grazing but also bee-hiving and collection of nontimber forest products. The rights of access are supposed to be issued by the County Council. The grazing regime is operated mainly by relatively large livestock owners that employ herders to oversee the animals up in the moorlands. Permanent settlement is not allowed. The County Council has a clear anthropocentric focus, with expectations that the area should contribute to the local economy both through tourism and pastoralism.

As indicated, Mt Elgon County Council has few possibilities to generate revenues to pay for management. They have, however, relatively good collaboration with KWS that track wildlife in the reserve and KWS has a large ranger outpost on the road up to CNR. This aspect of vertical interplay between the two PA regimes can positively contribute to the fitness of a TBPAM regime.

\section{GOING TRANSBOUNDARY? CHALLENGES FOR TBPAM ON ELGON}

We have presented and examined the diverse institutional and actor structures that have been established to govern Elgon's natural resources. We attempt to use the concepts of fit and interplay as earlier conceptualized to guide a discussion of the institutional challenges of fitting a TBPAM resource regime on Elgon. We use the criteria outlined in Table 1 as guidance.

\section{Fit: what PA governance issues are of relevance to TBPAM?}

The PAs on Elgon have been established mainly to govern the mountain's key ecosystem attributes, hence wildlife, forests, and water catchment resources. The rationale for a TBPAM regime would therefore be that it should facilitate a better fit with the attributes of these governance objects. The challenge is, however, if and how a TBPAM regime might offer a better overall fit with the ecosystem attributes at stake and how these are captured in the defined governance objectives.

Wildlife management would seem an obvious area in which TBPAM could offer a better fit to the ecosystem than separate PAs do. In Kenya, KWS has the mandate to track and conserve the wildlife in all PAs. This was well accepted by other PA authorities, and few major institutional obstacles were observed. As already emphasized, large wildlife is extinct on the Ugandan side. There is, however, no physical hindrance for wildlife to cross the border from Kenya because the Ugandan park enforces a ban on hunting. However, because poaching has continued to be a problem and "elephants don't forget," this has not been happening. Further, we have not found any records of important seasonal wildlife migration routes between the two sides of the mountain. Reintroduction of extinct wildlife is a part of KWS's strategy in Mt Elgon National Park, where wildlife has been relocated from other Kenyan parks. Reintroduction of wildlife has not been on the agenda on the Ugandan side, partly because of the ongoing debates with local communities on park boundary issues and reforestation efforts in park areas where boundary issues have been settled. Reintroduction of buffalos and elephants would most likely accelerate the ongoing park-community conflicts. This has great implications for the idea of a TBAPM regime to advance fitness of the current objectives of wildlife management on Elgon. This is distinctly different from many other PA complexes where this type of misfit is the main argument for TBPAM activity, hence joint management to cover wildlife migration range (Plumptre et al. 2007).

Forest governance has not been sustainable and there are records of forest degradation on both sides (White 2002, Nsita 2005). The deforestation processes on Elgon have been analyzed in detail (Petursson et al. 2012). This analysis revealed that the processes driving deforestation in the different PA units were not caused by a lack of spatial fit, but rather to multiple functional fit problems within the existing PA regimes and also to external political influence. It is not likely that a TBPAM regime could offer a better fit with respect to the forest resources on Elgon because the challenges are both national and local by nature.

Conserving water catchment functions is interrelated with forest conservation. Elgon is a mountain from where multiple rivers and streams radiate to the surrounding landscapes, lakes, and eventually the River Nile. The international boundary follows the rivers Malaba in the south and Suam in the north. There are thus few streams bisected by the international boundary. From a water governance point of view, there is no apparent need to combine the PA regimes on Elgon to advance water catchment functions, hence to provide better fitness, in this case.

When studying the fit between ecosystem properties and institutional arrangements noting the governance objectives involved according to the two criteria outlined in Table 1, we thus find few arguments from a fit perspective for a fully integrated TBPAM regime. On the contrary, there is evidence that models of smaller units tailored to more detailed ecosystem properties, as on the Kenyan side, might offer better 
fit to the ecosystems than a larger and more comprehensive regime.

\section{Some important forces of interplay that impact TBPAM on Elgon}

As shown, TBAPM will be instituted in a diverse landscape of institutions and actors, operating at different levels and existing interplay that will have significant impact on fitness. The PA organizations on Elgon, as common elsewhere, are mandated with governance objects beyond biodiversity resources, especially local community relations, tourism, and security. Therefore, what kind of horizontal and vertical interplays could be envisioned from a fully developed TBPAM?

\section{Forces of horizontal interplay that impact TBPAM}

At the international level, sovereignty is a key challenge for TBPAM. Although international relations between Uganda and Kenya are currently relatively good, there have been periods of tensions. Since independence, the cooperation between Uganda and Kenya was long dogged by political differences. Further, the regional body, East African Community (EAC) collapsed during the Amin years (Erixon 2003). At present, the political situation has become more stable, and the East African Community has been reestablished and is regarded legitimate and is also mandated to enhance regional cooperation (Busse and Shams 2003). During our fieldwork, the PA authorities had some general expectations toward EAC, but did not see its role, capacity, or competence in PA governance.

A key transboundary issue on tourism would be to ease the possibility for visitors to cross the mountain, and in particular to allow Kenyan visitors to access the highest peak found on the Ugandan side and then return. However, this is hardly a strong argument for reforming the PA governance structure. The key hindrance would be visa requirements for travelers crossing Uganda to Kenya and vice versa. If the two countries find this of mutual interest, this could be resolved outside the realm of the PA authorities.

At the national level, there are five different PA units on the mountain with different regimes, one in Uganda and four in Kenya. There is a good mutual understanding between the two conservation organizations UWA and KWS and good prospects for them to cooperate on specific transboundary issues. The other PA units have much less interest in such issues.

We found that the Mt Elgon County Council officials' interests in the TMPAM approach were largely based on expectations that such initiatives could generate possibilities for capacity building and support to their weak PA administration.

Because of the constant transfer of senior staff and low degree of institutional memory, personal contact across the boundary easily becomes sporadic, constraining informal cooperation.
Other studies have identified the importance of personal relationships for TBPAM success (Tanner et al. 2007).

The relations between PAs and local communities vary substantially between the PA regimes. Some regimes allow local community access, some take fees, while others do not allow any access, and for the Chepkitale National Reserve, management has been devolved to local government.

Security is another major PA governance issue, raised by all PA organizations as a potentially positive issue for transboundary cooperation. This relates to external matters such as cattle rustling, poaching, and that the PA can be a repository for banditry. There are also internal issues that have emerged from the PA administration such as PA boundary disputes, resettlement of local communities, crop raiding, and conflicts over access to resources. It is unlikely that any of the internal PA conflicts can be solved by the TBPAM regime. Moving to different institutional levels would hardly ease resolving conflicts such as resettlement or legal claims about PA boundaries.

Many external security issues that operate within the PAs have, however, truly transboundary elements that could benefit from increased transboundary cooperation. Both KWS and UWA are armed forces, mandated to engage in combating illegal activities, such as smuggling and cattle rustling, within the PA's and operate intelligence units active outside the PA areas. They cooperate with other forces such as police and both the Kenyan and the Uganda Armies have had security assignments within Elgon PAs. Therefore, increased transboundary security cooperation would demand cooperative mechanisms between actors far beyond the PA administration, such as the police, customs, and military.

\section{Forces of vertical interplay that impact TBPAM}

We found that international level actors are important driving forces in the TBPAM initiative on Elgon, primarily IUCN with NORAD funding (Muhweezi et al. 2007). IUCN initiated the issue, developed the project proposal, and was granted the authority to liaison and facilitate the TBPAM. Such donor initiatives are quite common in PA governance and TBPAM in Africa (Van Amerom 2002, Duffy 2007).

IUCN has been active on Elgon for a long time, on the Ugandan side since 1988 with Norwegian support and on the Kenyan side from 1998-2002 with Dutch support. The TBPAM pledge came from IUCN to NORAD, which became interested in 2001, partly to secure continuity on Elgon.

The top-down character of the TBPAM approach became apparent during our field work. The national level PA authorities had not taken the initiative to facilitate the approach, but were involved in developing the project. The donor funds associated with TBPAM were, however, of great interest for cash constrained administrations. The local communities and their local institutions had even less involvement. 
Table 4. Suggested institutional levels for management of some key governance objects in the protected areas (PA) on Mt Elgon. TBPAM $=$ transboundary protected area management.

\begin{tabular}{|c|c|c|}
\hline Key PA governance objects & Current management levels on Elgon & Suggested institutional levels to govern the PA object \\
\hline Forests & The forest resources are within each country & National, local \\
\hline $\begin{array}{l}\text { Nontimber forest products } \\
\text { (NTFR) }\end{array}$ & $\begin{array}{l}\text { The NTFR are used by the local communities, usually those } \\
\text { living adjacent to the PAs }\end{array}$ & National, local \\
\hline Wildlife & $\begin{array}{l}\text { Most large wildlife is extinct on the Ugandan side. The wildlife } \\
\text { on the Kenyan side is currently localized on that side. Some } \\
\text { vermin problems. }\end{array}$ & $\begin{array}{l}\text { National, local. Species specific TPBAM cooperation } \\
\text { needed in case of wildlife migration }\end{array}$ \\
\hline Water & $\begin{array}{l}\text { Most streams that radiate from Elgon do so within the same } \\
\text { country. }\end{array}$ & National issues on Mt Elgon. \\
\hline Tourism & $\begin{array}{l}\text { Tourism is localized on each side. Some interest is in cross } \\
\text { border trekking. }\end{array}$ & $\begin{array}{l}\text { National. TBPAM; cooperation needed in case of cross } \\
\text { border trekking. }\end{array}$ \\
\hline $\begin{array}{l}\text { Local } \\
\text { community } \\
\text { development }\end{array}$ & $\begin{array}{l}\text { Communities are highly dependent on access to various resources } \\
\text { within the PAs they live adjacent to. Most PA units allow some } \\
\text { access. }\end{array}$ & Local \\
\hline Security & $\begin{array}{l}\text { This relates mainly to using the PAs as a hideout or venue for } \\
\text { illegal activities and banditary }\end{array}$ & $\begin{array}{l}\text { National. Bilateral cooperation needed in some cases } \\
\text { but then often beyond the mandate of the PA } \\
\text { authorities. }\end{array}$ \\
\hline
\end{tabular}

The observed top-down approach can clearly be questioned, especially in light of the ongoing attempts toward devolving power to local level institutions. Our findings, therefore, add to the worries that the arrival of the TBPAM entails a "back to the barriers" in PA governance, recentralization and alienation of local level stakeholders' interest (Ribot et al. 2006, Hutton et al. 2005).

\section{What levels of cooperation should be the aim if engaging in TBPAM?}

In preceding sections we have asserted that there is a general, weak rationale for a fully integrated TBAPM regime on Elgon to improve fitness to defined ecosystem properties, and further, we have illustrated the different existing forces of interplay that may severely constrain the development of fully integrated TBPAM regimes on Elgon. TBPAM is thus no panacea even if two or more PA areas should happen to be physically adjoining.

Reflecting on possible, different levels of cooperation as outlined in Table 2, we thus do not find it necessary for the PA authorities to consider anything higher than the second level, which emphasizes information sharing and notification of actions and will entail lower transaction costs through more informal cooperation.

If the conservation organizations, especially KWS and UWA aim at formalizing the TBPAM issue, this should take place at their central office level instead of at the park level, where authority and capacity can gradually be built according to the objectives at level three in Table 2. Instead of formalizing TBPAM under a joint regime, we propose that the conservation authorities should formalize cooperation more generally with corresponding conservation authorities in neighboring countries. This would not include any devolution of power from the individual countries to an international TBPAM regime (Table 4).

\section{CONCLUSIONS AND POLICY CONSIDERATIONS}

This paper has analyzed the current PA resource regimes on Elgon in Uganda and Kenya and examined the constraints of fitting a TBPAM regime on the mountain. We have shown the numerous institutional fit and interplay challenges for establishment of a joint integrated TBPAM regime. Promoted from a conservation or natural resource perspective, we find the merging of adjoining PA regimes in two sovereign countries under a single joint, integrated resource regime a substantial institutional and policy challenge. We did not find TBPAM to provide any enhanced fit to the ecosystem attributes of Elgon according to our criteria, neither forestry, biodiversity, or water, nor does it fit with the existing institutional arrangements in the area embedded in the current PA regimes.

At first glance, a TBPAM regime might offer a better fit to the ecosystem involved. However, when analyzing the fitness with the ecosystem attributes of the key governance objects, forestry, wildlife, and water catchment, we do not find a justification for TBPAM offering a better fit on Elgon. There has to be an apparent need on the part of the countries involves to consider devolving power from the principle of sovereignty toward a TBPAM regime. We do not find such strong reasons on Elgon, and actually, many of the transboundary issues raised by the PA authorities are beyond the realms of PA governance. Secondly, the new TBPAM idea enters a complex existing institutional landscape where institutional interplays are significant forces. Therefore, an idea to merge the current institutions that have evolved over decades of power struggles, 
bargains, and reflecting various interests is a daunting challenge.

Cooperation between the managerial organizations is no less of an intra-national than a transboundary challenge. The different structures of the three Kenyan organizations have significant implications for their capacity to work on transboundary issues and further, it would also make cooperation more complicated for the single Ugandan counterpart.

We believe that Elgon provides an informative case for studying the TBPAM challenges in detail and it allows for testing out the institutional analytical frameworks we have applied. We suggest that the analytical frameworks on which we have elaborated can be generally applied to study institutional landscapes when deciding upon a path toward more appropriate levels and types of cooperation between adjoining PAs.

Based on our findings, there are reasons to be critical to the perceived benefits of the TBPAM strategy in the form of one, fully integrated regional regime (Table 2). We do not find evidence for such a regime providing a better fit to Elgon ecosystem attributes and a multitude of complex interplay challenges that constrain TBPAM approach.

Because most current PA governance challenges are national or local by nature, there is a risk that the current TBPAM approach counteracts local community conservation attempts (Fall 2003, Hutton et al. 2005). Instead of addressing the appropriate horizontal institutional interplay constraints, it moves issues along vertical levels to different spatial scales, where local community governance is even more alienated and complicated. Moving to international negotiations brings back the central government as the decisive legitimate management authority. On Elgon, the TBPAM process has been top-down and also donor driven from the early beginning. Such policies and emerging institutions encounter the risk of lacking local community legitimacy and little mutual understanding, hence increasing the risk of misfits. We fear that the current interest in TBPAM can rather imply a backward step in the much needed PA reforms in Africa, not allowing for comprehensive local community involvement and rights-based empowerment.

Entering a TBPAM should not be an objective in itself, even if two PAs happen to be adjoining. We encourage policy makers to approach it more critically if the daunting exercise of a continuum of TBPAM governance toward fully integrated management within a joint TBPAM regime will advance fitness to the ecosystem attributes.

Instead, the focus should be on identifying the issues that are truly transboundary in nature and construct governance structures that directly fit these. Such issues can be gradually addressed on demand. This could apply in cases in which large wildlife, especially an elephant herd, rises in numbers and starts to utilize both sides of the mountain. Then there might be a risk for a misfit between the current PA regime and wildlife and a need for a TBPAM cooperation to enhance fitness. Such disaggregated cooperation on specific issues entails other and less complex institutional structures than bringing the PAs under a joint management regime.

At first glance it may seem like an easy matter to talk about the fit of PA regimes on Elgon, hence one mountain, one PA regime. However, the mountain has been divided between Uganda and Kenya for a long time, first by the colonial rule that created the international boundary and then the different postcolonial histories of the independent states to date. The landscapes of two sides of the mountain are different, as are the social relations and governance strategies in the respective PAs. Based on our analysis of the character of the ecosystem attributes, the interplay of different social relations clearly indicates that a TBPAM regime would not provide a better fit to the current PA governance challenges. One size does not fit all.

${ }^{[1]}$ Young $(2002,2008)$ tend to define interplay as interaction between specific governance systems or resource regimes. Hence, we may again have expanded the concept beyond the confines he has defined - see Vatn and Vedeld (2012) for a discussion.

${ }^{[2]}$ Total funding for the transboundary Elgon project from Norad is USD 4.8 million over a four-year period (September 2005-August 2009) and USD 2.7 million for the period 2009-2010.

${ }^{[3]}$ A parish is a local government unit in Uganda. Around 60 parishes border Mt Elgon National Park in Uganda.

Responses to this article can be read online at: http://www.ecologyandsociety.org/issues/responses. php/5729

\section{Acknowledgments:}

Thanks to Dr. John Kabbogoza for various support in gathering information in Uganda and Kenya. Further we want to express our appreciation to all who assisted during the fieldwork in the Elgon area. This research was made possible with financial support from the Icelandic Development Agency (ICEIDA), Iceland Forest Service Research Station Mogisla, and Icelandic Forestry Association.

\section{LITERATURE CITED}

Adams, W., and J. Hutton. 2007. People, parks and poverty: political ecology and biodiversity conservation. Conservation and Society 5(2):147-183. 
Ansell, C. K., and S. Weber. 1999. Organizing international politics: sovereignty and open systems. International Political Science Review/Revue internationale de science politique 20 (1):73-93. http://dx.doi.org/10.1177/0192512199201004

Baatvik, S. T., J. R. S. Kaboggoza, C. Kabutha, and P. Vedeld. 2002. Mt. Elgon Regional Ecosystem Conservation Programme (MERECP) appraisal report. Noragric Report. Norwegian University of Life Sciences, Ås, Norway.

Barrett, C. B., K. Brandon, C. Gibson, and H. Gjertsen. 2001. Conserving tropical biodiversity amid weak institutions. BioScience 51(6):497-502. http://dx.doi.org/10.1641/0006-3568 (2001)051[0497:CTBAWI]2.0.CO;2

Barrow, E., H. Gichohi, and M. Infield. 2001. The evolution of community conservation policy and practice in East Africa. Pages 59-73 in D. Hulme and M. W. Murphree, editors. African Wildlife and Livelihoods. James Currey, London, UK.

Bawa, K. S., R. Seidler, and P. H. Raven. 2004. Reconciling conservation paradigms. Conservation Biology 18(4):859-860. http://dx.doi.org/10.1111/j.1523-1739.2004.01838.x

Braack, L., T. Sandwith, D. Peddle, and T. Petermann. 2006. Security considerations in the planning and management of transboundary conservation areas. International Union for Conservation of Nature, Gland, Switzerland.

Brockington, D., J. Igoe, and K. Schmidt-Soltau. 2006. Conservation, human rights, and poverty reduction. Conservation Biology 20(1):250-252. http://dx.doi.org/10.1111/ j.1523-1739.2006.00335.x

Brown, K. 2003. Integrating conservation and development: a case of institutional misfit. Frontiers in Ecology and the Environment 1(9):479-487. http://dx.doi.org/10.1890/1540-9295 (2003)001[0479:ICADAC]2.0.CO;2

Busch, J. 2008. Gains from configuration: the transboundary protected area as a conservation tool. Ecological Economics 67(3):394-404. http://dx.doi.org/10.1016/j.ecolecon.2007.12.012

Busse, M., and R. Shams. 2003. Trade effects of the East African community: do we need a transitional fund? Discussion paper no. 240. Hamburg Institute of International Economics, Hamburg, Germany.

Chape, S., J. Harrison, M. Spalding, and I. Lysenko. 2005. Measuring the extent and effectiveness of protected areas as an indicator for meeting global biodiversity targets. Philosophical Transactions of the Royal Society, Series B 360:443-455. http://dx.doi.org/10.1098/rstb.2004.1592

Child, B. 2004. Parks in transition. Earthscan, Sterling, Virginia, USA.

Cleaver, F. 2002. Reinventing institutions: bricolage and the social embeddedness of natural resource management.
European Journal of Development Research 14(2):11-30. http://dx.doi.org/10.1080/714000425

Duffy, R. 2007. Peace parks and global politics: the paradoxes and challenges of global governance. Pages 55-68 in H. S. Ali. editor. Peace parks: conservation and conflict resolution. MIT, Cambridge, Massachusetts, USA.

Ekstrom, J. A., and O. R. Young. 2009. Evaluating functional fit between a set of institutions and an ecosystem. Ecology and Society 14(2): 16. [online] URL: http://www.ecologyandsociety. org/vol14/iss2/art16/

Erixon, F. 2003. Poverty and recovery: the history of aid and development in East Africa. Economic Affairs 23(4):27-33. http://dx.doi.org/10.1111/j.1468-0270.2003.00440.x

Fakir, S. 2000. Transfrontier conservations areas: a new dawn for eco-tourism, or a new form of conservation expansionism. International Union for Conservation of Nature Policy Think Tank Series, Vol. 3. Pretoria, South Africa.

Fall, J. 2003. Planning protected areas across boundaries: new paradigms and old ghosts. Journal of Sustainable Forestry 17 (1/2):81-102. http://dx.doi.org/10.1300/J091v17n01_06

Fall, J. 2005. Drawing the line: nature, hybridity and politics in transboundary spaces. Ashgate, Farnham, UK.

Fall, J. 2009. Beyond handshakes: rethinking cooperation in transboundary protected areas as a process of individual and collective identity construction. Journal of Alpine Research 2:73-84.

Folke, C., L. Pritchard, F. Berkes, J. Colding, and U. Svedin. 2007. The problem of fit between ecosystems and institutions: ten years later. Ecology and Society 12(1): 30. [online] URL: http://www.ecologyandsociety.org/vol12/iss1/art30/

Gibson, C. 1999. Politicians and poachers: the political economy of wildlife policy in Africa. Cambridge University Press, Cambridge, UK. http://dx.doi.org/10.1017/ CBO9780511625640

Hitimana, J., J. Legilisho Kiyiapi, and J. Thairu Njunge. 2004. Forest structure characteristics in disturbed and undisturbed sites of Mt. Elgon Moist Lower Montane Forest, western Kenya. Forest Ecology and Management 194(1-3):269-291. http://dx.doi.org/10.1016/j.foreco.2004.02.025

Howard, P. 1991. Nature conservation in Uganda's tropical forest reserves. IUCN, Gland, Switzerland.

Hutton, J., W. Adams, and J. Murombedzi. 2005. Back to the barriers? Changing narratives in biodiversity conservation. Forum for Development Studies 32(2):341-370. http://dx.doi. org/10.1080/08039410.2005.9666319 
International Union for Conservation of Nature (IUCN). 1994. Guidelines for protected area management categories. IUCN, Gland, Switzerland.

Kenya Forest Department and Kenya Wildlife Service (KFD/ KWS). 2001. Mt. Elgon integrated management plan. KFD/ KWS, Nairobi, Kenya.

McEwen, A. 1971. International boundaries of East Africa. Clarendon Press, Oxford, UK.

Médard, C. 2010. "Indigenous" land claims in Kenya: a case study of Chebyuk, Mount Elgon District. Pages 19-36 in W. Anseeuw and C. Alden, editors. The struggle over land in Africa: conflicts, politics and change. HSRC Press, South Africa.

Moss, T. 2004. The governance of land use in river basins: prospects for overcoming problems of institutional interplay with the EU Water Framework Directive. Land use Policy 21:85-94. http://dx.doi.org/10.1016/j.landusepol.2003.10.001

Muhweezi, A., G. Sikoyo, and M. Chemonges. 2007. Introducing a transboundary ecosystem management approach in the Mount Elgon region. Mountain Research and Development 27(3):215-219 http://dx.doi.org/10.1659/0276-4741 (2007)27[215:IATEMA]2.0.CO;2

Munthali, S. M. 2007. Transfrontier conservation areas: integrating biodiversity and poverty alleviation in Southern Africa. Natural Resources Forum 31(1):51-60. http://dx.doi. org/10.1111/j.1477-8947.2007.00130.x

Myrhen, S.-M. 2007. Rural livelihood and forest management in Mount Elgon, Kenya. Thesis, Noragric, Norwegian University of Life Sciences, Ås, Norway.

Naughton-Treves, L., M. B. Holland, and K. Brandon. 2005. The role of protected areas in conserving biodiversity and sustaining local livelihoods. Annual Review of Environment and Resources 30(1):219-252. http://dx.doi.org/10.1146/ annurev.energy.30.050504.164507

Neumann, R. P. 1998. Imposing wilderness: struggles over livelihood and nature preservation in Africa. University of California Press, Berkeley, California, USA.

Newmark, W. D. 2008. Isolation of African protected areas. Frontiers in Ecology and Environment 6(6):321-328. http:// dx.doi.org/10.1890/070003

Norgrove, L., and D. Hulme. 2006. Confronting conservation at Mount Elgon, Uganda. Development and Change 37 (5):1093-1116. http://dx.doi.org/10.1111/j.1467-7660.2006.00514. $\underline{x}$

North, D. 1990. Institutions, institutional change and economic performance. Cambridge University Press, Cambridge, UK.. http://dx.doi.org/10.1017/CBO9780511808678
Nsita, S. A. 2005. Decentralization and the forest management in Uganda. Pages 184-196 in C. J. P. Colfer and D. Capistrano, editors. The politics of decentralization: forests, power and people. Earthscan, London, UK.

Ostrom, E. 1990. Governing the commons: the evolution of institutions for collective action. Political economy of institutions and decisions. Cambridge University Press, Cambridge, UK. http://dx.doi.org/10.1017/CBO9780511807763

Ostrom, E., R. Gardner, and J. Walker. 1994. Rules, games, and commonpool resources. University of Michigan Press, Ann Arbor, Michigan, USA.

Oakersson, R. J. 1992. Analyzing the commons: a framework. Pages 41-59 in D. Bromley, editor. Making the commons work. Theory, practice and policy. ICS, San Francisco, California, USA.

Petursson, J. G., P. Vedeld, and J. Kaboggoza. 2011. Transboundary biodiversity management: institutions, local stakeholders and protected areas: a case study from Mt Elgon, Uganda and Kenya. Society \& Natural Resources 24 (12):1304-1321. http://dx.doi.org/10.1080/08941920.2010.540310

Plumptre, A., D. Kujirakwinja, A. Treves, I. Owiunji, and H. Rainer. 2007. Transboundary conservation in the greater Virunga landscape: its importance for landscape species. Biological Conservation 134(2):279-287. http://dx.doi. org/10.1016/i.biocon.2006.08.012

Ribot, J. C., A. Agrawal, and A. M. Larson. 2006. Recentralizing while decentralizing: how national governments reappropriate forest resources. World Development 34 (11):1864-1886. http://dx.doi.org/10.1016/j.worlddev.2005.11.020

Robbins, P. 2004. Political ecology: a critical introduction. Blackwell, Oxford, UK.

Scott, W. R. 1995. Institutions and organizations. Sage, Thousand Oaks, California, USA.

Scott, P. 1998. From conflict to collaboration. People and forests at Mount Elgon, Uganda. International Union for Conservation of Nature, Gland, Switzerland.

Soini, E. 2007. Past and present land tenure and incentives for land management in the five districts surrounding Mount Elgon. Mt. Elgon Regional Ecosystem Conservation Programme, Nairobi, Kenya and International Union for Conservation of Nature, Gland, Switzerland..

Tanner, R., W. Freimund, B. Hayden, and B. Dolan. 2007. The Waterton-Glacier International Peace Park: conservation amid border security. In H. S. Ali, editor. Peace parks: conservation and conflict resolution. MIT, Cambridge, Massachusetts, USA.

Taylor, M. 1987. The possibility of cooperation. Cambridge University Press, Cambridge, UK. 
Uganda Wildlife Authority (UWA). 2000. Mt. Elgon National Park: general management plan. UWA, Kampala, Uganda.

Van Amerom, M. 2002. National sovereignty and transboundary protected areas in Southern Africa. GeoJournal 58(4):265-273. http://dx.doi.org/10.1023/B:GEJO.0000017957.42266. $\underline{\mathrm{d} 5}$

Vatn, A. 2005. Institutions and the environment. Edward Elgar, Cheltenham, UK.

Vatn, A., and P. Vedeld. 2012. Fit, interplay, and scale: a diagnosis. Ecology and Society 17(4): 12. http://dx.doi. org/10.5751/ES-05022-170412

Vedeld, P., A. van Rooji, and F. Sundnes. 2005. Final appraisal of Mt. Elgon Regional Ecosystem Conservation Programme (MERECP). Consultancy Report to Norad. Noragric Report No. 25. Noragric, Norwegian University of Life Sciences, Ås, Norway.

White, S. 2002. People - park conflicts in Mt Elgon. The role of collaborative management in conflict resolution. Paper presented at the National Conference on Mountains and Highlands in Uganda, 3-4 October. Makere University, Kampala, Uganda.

Young, O. R. 2002. The institutional dimensions of environmental change: fit, interplay and scale. MIT, Cambridge, Massachusetts, USA.

Young, O. R. 2008. Institutions and environmental change. The scientific legacy of a decade of IDGEC research. Pages 3-47 in O. R. Young, L. A. King and H. Schroeder, editors. Institutions and environmental change. Principal findings, applications and research frontiers. MIT, Cambridge, Massachusetts, USA.

Zbicz, D. C. 1999. The "nature" of transboundary cooperation. Environmental Conservation 41:15-16. 